\title{
Protective and Therapeutic Effects of Moringa Oleifera Against Toxicity of Lead Chloride
}

\author{
Kadry A. ELbakry ${ }^{1}$, Naglaa F. Elarabany ${ }^{1}$ and Samaa G. Behery ${ }^{* 1}$ \\ 1 Zoology Department, Faculty of Science, Damietta University, New Damietta, Egypt
}

Received: 8 February 2018 /Accepted: 25 March 2018

* Corresponding author: samaa.behery@yahoo.com

\begin{abstract}
The present study aimed to evaluate the protective and therapeutic effects of Moringa oleifera leaves against toxicity induced by lead chloride in albino rats male. Thirty-six albino rats weighing about 182.8 gm were divided into 6 groups each of 6 rats. Control group, left without treatment. The lead chloride group treated orally with $200 \mathrm{mg}$ lead chloride daily for 30 days. The Moringa oleifera group treated orally with $200 \mathrm{mg}$ Moringa oleifera daily for 30 days. Lead + Moringa oliefera group (200 mg lead chloride $+200 \mathrm{mg}$ Moringa oliefera). Therapeutic group (200 mg lead chloride followed by $200 \mathrm{mg}$ Moringa oleifera) and protective group (200 mg Moringa oleifera followed by $200 \mathrm{mg}$ lead chloride). At the end of the experiment, both kidney and liver function tests were assayed as well as catalase and SOD enzymes activity and MDA level. The activity of ALT and the levels of bilirubin, urea, creatinine, cholesterol, ammonia, urea and triglycerides were elevated after lead administration compared with the control and protective groups $(p<0.05)$ but the level of albumin of the same group was decreased compared with the control group. In protective group, the level of MDA was significantly decrease compared with that of the lead group. On the other hand, the activities of SOD and catalase were significantly increase in the protective group as well as other treated groups compared with the control group $(\mathrm{p}<0.05)$. In conclusion, treatment with MO leaves can protect liver and kidney against lead toxicity.
\end{abstract}

Keywords: Moringa oleivera, Lead, Liver, Kidney, Rats.

\section{Introduction}

Lead is considered as one of the major environmental pollutants and is amongst four metals that have the most detrimental effects on human (Karrari etal, 2012). It is known to induce a broad range of physiological, biochemical, and behavioural dysfunctions in laboratory animals and humans (Flora etal., 2016), including central and peripheral nervous systems (Bressler etal., 1999), haemopoietic system (Lanphear et al.,2000), cardiovascular system (Khalil et al.,1993) ,kidneys (Abdel Moneim et al., 2011), liver (Omotoso et al.,2015) and male (Lancranjan et al., 1975) and female reproductive systems (Ronis, etal., 1998). Lead interferes with bio-systems by alterations in their molecular interactions, signaling processes, and ultimately cellular function (Skerfving and Bergdahl, 2007).

Lead has been linked with high incidence of renal dysfunction with attendant glomerular and tubulointerstitial changes, resulting in chronic kidney disease, hypertension as well as hyperuricaemia (Rastogi, 2008). 
Studies have shown that lead exposure to laboratory animals raised lipid peroxidation or lowered antioxidant defense mechanism (Bokara et al., 2008; Adegbesan and Adenuga, 2007). Some researchers further showed that the level of lipid peroxidation has a direct relationship with lead concentration in brain regions (Saxena and Flora, 2006) and in liver of lead exposed rats (Sandhir R, Gill KD, 1995).

Natural plants have drawn much attention for their pharmacological effects in the treatment and prevention of various diseases due to their high biocompatibility, low toxicity, and potential biological activity. Among them, M. oleifera is known to be important for the synthesis of useful drugs (Wadhwa, ET AL., 2013) that can serve medicinal purposes; they also have important agricultural, commercial and economical values.

Almost all the parts of $M O$ are extensively used for the treatment of inflammation, (Mahajan et al., 2008) cardiovascular and liver disease (Omotoso et al., 2015) hematological and renal function (Gupta et al., 2005) and metal intoxications including cadmium (Toppo et al., 2015) and lead (Onah et al., 2016). The present study was conducted to investigate the effects of aqueous leaf extract of Moringa oleifera as hepato-renal protective agent against lead toxicity in rats.

\section{Materials and Methods}

All chemicals were purchased from the Scientific Office in Damietta, Egypt.

\section{Plant Extraction}

Moringa oleifera leaves were obtained from the Agricultural Research Center in Cairo, Egypt.

\section{Preparation of extract}

The leaves were dried then crushed into coarse powder. About $200 \mathrm{mg}$ from the powder were soaked in $18 \mathrm{ml}$ distilled water for about 24 hours, then filtered and the desired volume was administered orally.

\section{Experimental animals}

Thirty-six albino rats (weighed about $182.81 \pm$ $6.6 \mathrm{gm}$ ) were obtained from Mansoura University Lab. The experimental rats were housed in the animal house in Zoology Department, Faculty of Science, Damietta University, New Damietta,
Egypt. They were housed in plastic cages under controlled temperature and allowed to adapt for two weeks. Liscence for animal handling.

\section{Experimental design}

6 groups, six rats per each group assigned as followed:

Control group: left without treatment for 30 days.

Lead chloride group: treated with $200 \mathrm{mg}$ orally lead chloride daily for 30 days.

Moringa oliefera group: treated with $200 \mathrm{mg}$ orally Moringa oliefera_daily for 30 days.

Lead + Moringa oliefera group: treated with 200 mg orally lead chloride $+200 \mathrm{mg}$ orally Moringa oliefera daily at the same time for 30 days.

Therapeutic group: was treated with $200 \mathrm{mg}$ orally lead chloride daily for 30 days followed by $200 \mathrm{mg}$ orally Moringa oliefera daily for another 30 days.

Protective group: was treated with $200 \mathrm{mg}$ orally Moringa oliefera daily for 30 days followed by $200 \mathrm{mg}$ orally lead chloride daily for another 30 days.

\section{Haematological measurements}

At the end of experiment, rats were sacrificed using chloroform and blood samples were collected directly form heart of each rat; one part of blood was collected into heparinized tubes for haematological determinations. The other part was collected without anticoagulant agent to prepare serum. The collected serum was used for liver and kidney functions parameters by using automated analyzer and available commercial kits.

\section{Statistical analysis}

The differences between the groups was estimated by the statistical analysis using one-way anova and Tukey tests. A p value less than 0.05 was considered significant.

\section{Results}

Physiological studies

\section{Haematological Parameters}

Table 1 shows the activity of haematological parameters of male albino rats. WBCs was significantly higher in Therapeutic group and 
Protective group than groups control, Moringa olievera, Lead chloride and $(\mathrm{M}+\mathrm{Pb}),(\mathrm{P}<0.006)$. In addition, Monocytes count was significantly higher in Therapeutic group and Protective group than Lead chloride, $(\mathrm{P}<0.05)$. On the other hand, Lymphocyte was significantly lower in group Moringa olievera and Moringa olievera + Lead chloride than groups Therapeutic group and Protective group; $(\mathrm{P}<0.01)$.

\section{Liver \& Kidney Functions :}

Table 2 shows the serum activity of liver and kidney enzymes of male albino rats.

ALT activity was significantly higher in Therapeutic group compared to all other groups ( $\mathrm{P}$ $<0.0004$ ), While Albumin concentration was significantly higher in Therapeutic group than control group, Moringa olievera and $(\mathrm{M}+\mathrm{Pb}),(\mathrm{P}$ $<0.02$ ). Ammonia activity was significantly higher in Therapeutic group than all other groups except control group, $(\mathrm{P}<0.04)$. While Urea was significantly higher in $(\mathrm{M}+\mathrm{Pb})$ than all other groups, ( $\mathrm{P}<0.04)$.On the other hand, Creatinine concentration value was significantly lower in group Protective group than Moringa olievera and Therapeutic group, $(\mathrm{P}<0.04)$.

While Cholesterol concentration value was significantly lower in $(\mathrm{M}+\mathrm{Pb})$ than all other groups, ( $\mathrm{P}<0.04)$.

\section{Antioxidant Enzymes Studies :}

Table 4 showed antioxidant enzymes activity of male albino rats. MDA activity was significantly higher in Protective group than groups control, Moringa olievera and $(\mathrm{M}+\mathrm{Pb}),(\mathrm{P}<0.04)$.

Also both SOD and CAT activity was significantly higher in Moringa olievera, Lead chloride, $(\mathrm{M}+\mathrm{Pb})$, Therapeutic group and Protective group than control group, $(\mathrm{P}<0.002$ and $<0.004$, respectively).

Table (1): Haematocrit (PCV), haemoglobin ( $\mathrm{Hb})$ and haematimetric indices of albino rats treated with lead chloride only and / or Moringa oleifera for a period of 30 days.

\begin{tabular}{l|l|l|l|l|l|l|l}
\hline & \multicolumn{1}{|c|}{$\begin{array}{l}\text { Groups } \\
\text { Control } \\
\text { Parameters }\end{array}$} & $\begin{array}{c}\text { Moringa } \\
\text { olievera } \\
(\mathrm{n}=6)\end{array}$ & $\begin{array}{c}\text { Lead } \\
\text { chloride } \\
(\mathrm{n}=6)\end{array}$ & $\begin{array}{c}\text { Moringa } \\
\text { olievera }+ \\
\text { Lead chloride } \\
(\mathrm{n}=6)\end{array}$ & $\begin{array}{l}\text { Therapeutic } \\
\text { group (n=6) }\end{array}$ & $\begin{array}{c}\text { Protective } \\
\text { group (n=6) }\end{array}$ & P value \\
\hline $\mathrm{Hb}(\mathrm{g} / \mathrm{dl})$ & $8.3 \pm 0.5$ & $8.9 \pm 0.4$ & $9.8 \pm 0.4$ & $9.2 \pm 0.5$ & $9.7 \pm 0.8$ & $10 \pm 0.9$ & $\mathrm{NS}$ \\
\hline $\mathrm{RBCs}\left(10^{6} / \mu \mathrm{l}\right)$ & $2.4 \pm 0.2$ & $2.8 \pm 0.2$ & $2.9 \pm 0.3$ & $2.5 \pm 0.2$ & $3.2 \pm 0.3$ & $3.4 \pm 0.4$ & $\mathrm{NS}$ \\
\hline $\mathrm{WBCs}\left(10^{3} / \mu \mathrm{l}\right)$ & $2.7 \pm 0.3^{\mathrm{a}}$ & $2.7 \pm 0.3^{\mathrm{a}}$ & $3.4 \pm 0.1^{\mathrm{a}}$ & $3.1 \pm 0.3^{\mathrm{a}}$ & $5.5 \pm 0.5^{\mathrm{b}}$ & $4.9 \pm 0.5^{\mathrm{b}}$ & $<0.006$ \\
\hline Lymphocyte $(\%)$ & $61 \pm 11.1^{\mathrm{ab}}$ & $50.8 \pm 7.5^{\mathrm{b}}$ & $27.8 \pm 3.2^{\mathrm{b}}$ & $51.4 \pm 10.6^{\mathrm{ab}}$ & $73 \pm 8.5^{\mathrm{a}}$ & $75.4 \pm 11.2^{\mathrm{a}}$ & $<0.01$ \\
\hline Monocytes $(\%)$ & $6 \pm 0.7$ & $4.7 \pm 0.6^{\mathrm{ab}}$ & $4.3 \pm 0.4^{\mathrm{b}}$ & $4 \pm 0.4^{\mathrm{ab}}$ & $4.7 \pm 0.3^{\mathrm{a}}$ & $3.6 \pm 0.24^{\mathrm{a}}$ & $<0.05$ \\
\hline Eosinophil $(\%)$ & $2.7 \pm 0.3$ & $2.7 \pm 0.4$ & $2 \pm 0.5$ & $2.7 \pm 0.4$ & $4.2 \pm 0.5$ & $3 \pm 0.8$ & $\mathrm{NS}$ \\
\hline
\end{tabular}

Values are means \pm S.E.M. Values with different superscript letters within each row are significantly different (analysis of variance, $\mathrm{P}<0.05$ ). NS, non-significant.

Table (2): Liver functions, Kidney functions and lipid profile of male albino rats treated with lead chloride only and / or Moringa olievera for a period of 30 days.

\begin{tabular}{|c|c|c|c|c|c|c|c|}
\hline Groups & $\begin{array}{l}\text { Control } \\
(n=6)\end{array}$ & $\begin{array}{c}\text { Moringa } \\
\text { olievera } \\
(n=6)\end{array}$ & $\begin{array}{c}\text { Lead } \\
\text { chloride } \\
(n=6)\end{array}$ & \begin{tabular}{|c|} 
Moringa \\
olievera + Lead \\
chloride $(n=6)$ \\
\end{tabular} & $\begin{array}{l}\text { Therapeutic } \\
\text { group }(n=6)\end{array}$ & $\begin{array}{c}\text { Protective } \\
\text { group }(n=6)\end{array}$ & $\begin{array}{c}* \mathrm{P} \\
\text { value }\end{array}$ \\
\hline ALT(U/ml) & $41.3 \pm 2.2^{\mathrm{a}}$ & $54.7 \pm 3.2^{\mathrm{a}}$ & $52.3 \pm 7.3^{\mathrm{a}}$ & $46.3 \pm 3.2^{\mathrm{a}}$ & $89.8 \pm 8.5^{b}$ & $58.8 \pm 1.7^{\mathrm{a}}$ & $<0.0004$ \\
\hline AST(U/ml) & $22.7 \pm 2.5$ & $24 \pm 1.8$ & $21 \pm 1.7$ & $21.8 \pm 1.5$ & $19.8 \pm 1.7$ & $21.2 \pm 1.4$ & $\mathrm{NS}$ \\
\hline $\mathrm{TP}(\mathrm{gm} / \mathrm{dl})$ & $5.3 \pm 1.7$ & $10.3 \pm 0.7$ & $4.73 \pm 0.55$ & $7.7 \pm 0.6$ & $8.4 \pm 0.9$ & $8.9 \pm 0.3$ & NS \\
\hline $\begin{array}{l}\begin{array}{l}\text { Albumin } \\
(\mathrm{gm} / \mathrm{dl})\end{array} \\
\end{array}$ & $2.6 \pm 0.1^{\mathrm{ab}}$ & $1.6 \pm 0.4^{b}$ & $2.34 \pm 0.19^{\mathrm{ac}}$ & $2.5 \pm 0.2^{\mathrm{ab}}$ & $3.8 \pm 0.2^{c}$ & $3.1 \pm 0.3^{\mathrm{ac}}$ & $<0.02$ \\
\hline $\begin{array}{l}\text { Ammonia } \\
(\mathrm{gm} / \mathrm{dl})\end{array}$ & $114 \pm 35.8^{\mathrm{ab}}$ & $111.8 \pm 32.3^{b}$ & $99.2 \pm 19.3^{\mathrm{b}}$ & $67.5 \pm 15.8^{b}$ & $209 \pm 57.9^{\mathrm{a}}$ & $83.7 \pm 27.1^{b}$ & $<0.04$ \\
\hline Urea (mg/dl) & $92.7 \pm 12.4^{\mathrm{a}}$ & $176.6 \pm 48.9^{\mathrm{ab}}$ & $366.7 \pm 28.3^{b}$ & $546 \pm 60.4^{c}$ & $179.8 \pm 79.8^{\mathrm{a}}$ & $79.1 \pm 3.4^{\mathrm{a}}$ & $<0.04$ \\
\hline $\begin{array}{l}\text { Uric Acid } \\
(\mathrm{mg} / \mathrm{dl})\end{array}$ & $4.5 \pm 1.2$ & $3.9 \pm 0.5$ & $4.3 \pm 0.9$ & $4.6 \pm 0.7$ & $4.3 \pm 0.5$ & $4.5 \pm 0.7$ & NS \\
\hline $\begin{array}{l}\text { T. Bilirubin } \\
(\mathrm{mg} / \mathrm{dl})\end{array}$ & $2.4 \pm 0.5$ & $3.9 \pm 0.1$ & $4.7 \pm 0.8$ & $3.5 \pm 0.6$ & $3.4 \pm 0.6$ & $4.5 \pm 0.7$ & NS \\
\hline $\begin{array}{l}\text { Creatinine } \\
(\mathrm{gm} / \mathrm{dl})\end{array}$ & $2.5 \pm 0.3^{\mathrm{ab}}$ & $2.9 \pm 0.3^{\mathrm{a}}$ & $2.8 \pm 0.3^{\mathrm{ab}}$ & $2.7 \pm 0.3^{\mathrm{ab}}$ & $3.2 \pm 0.3^{\mathrm{a}}$ & $2 \pm 0.2^{b}$ & $<0.04$ \\
\hline
\end{tabular}

Values are means \pm S.E.M. Values with different superscript letters within each row are significantly different (analysis of variance, $\mathrm{P}<0.05)$. NS, non-significant. 
Table (3): lipid profile of male albino rats treated with lead chloride only and / or Moringa olievera_for a period of 30 days.

\begin{tabular}{l|l|l|l|l|l|l|l}
\hline Groups & \multicolumn{1}{|c|}{$\begin{array}{c}\text { Control } \\
(\mathrm{n}=6)\end{array}$} & $\begin{array}{c}\text { Moringa } \\
\text { olievera } \\
(\mathrm{n}=6)\end{array}$ & $\begin{array}{c}\text { Lead } \\
\text { chloride } \\
(\mathrm{n}=6)\end{array}$ & $\begin{array}{c}\text { Moringa } \\
\text { olievera } \\
\text { Lead } \\
\text { chloride } \\
(\mathrm{n}=6)\end{array}$ & $\begin{array}{c}\text { Therapeutic } \\
\text { group } \\
(\mathrm{n}=6)\end{array}$ & $\begin{array}{c}\text { Protective } \\
\text { group } \\
(\mathrm{n}=6)\end{array}$ & $* \mathrm{P}$ value \\
\hline $\begin{array}{l}\text { Cholesterol } \\
(\mathrm{mg} / \mathrm{dl})\end{array}$ & $294.4 \pm 28^{\mathrm{a}}$ & $237.1 \pm 39.2^{\mathrm{a}}$ & $214.1 \pm 15.1^{\mathrm{a}}$ & $128.1 \pm 13.4^{\mathrm{b}}$ & $224 \pm 44.6^{\mathrm{a}}$ & $254.9 \pm 44.3^{\mathrm{a}}$ & $<0.04$ \\
\hline $\begin{array}{l}\text { Triglycerides } \\
(\mathrm{mg} / \mathrm{dl})\end{array}$ & $91.2 \pm 9.8$ & $110.4 \pm 15.6$ & $65.9 \pm 7.4$ & $84.5 \pm 15.3$ & $103.8 \pm 25.7$ & $83.3 \pm 14.3$ & $\mathrm{NS}$ \\
\hline $\begin{array}{l}\text { Glucose } \\
(\mathrm{gm} / \mathrm{dl})\end{array}$ & $92.9 \pm 9.6$ & $101.7 \pm 0.13$ & $95.1 \pm 1.8$ & $94.6 \pm 6.5$ & $102.5 \pm 1.5$ & $89.9 \pm 6.6$ & $\mathrm{NS}$ \\
\hline
\end{tabular}

Values are means \pm S.E.M. Values with different superscript letters within each row are significantly different (analysis of variance, $\mathrm{P}<0.05)$. NS, non-significant.

Table (4): Lipid peroxidation, superoxide dismutase and catalase activity of male albino rats treated with lead chloride only and / or Moringa olievera for a period of 30 days

\begin{tabular}{|c|c|c|c|c|c|c|c|}
\hline Group & $\begin{array}{c}\text { Control } \\
(n=6)\end{array}$ & $\begin{array}{c}\text { Moringa } \\
\text { olievera } \\
(n=6)\end{array}$ & $\begin{array}{c}\text { Lead } \\
\text { chloride } \\
(n=6)\end{array}$ & $\begin{array}{c}\text { Moringa } \\
\text { olievera }+ \\
\text { Lead } \\
\text { chloride } \\
(n=6)\end{array}$ & $\begin{array}{l}\text { Therapeuti } \\
\text { c group } \\
(n=6)\end{array}$ & $\begin{array}{l}\text { Protective } \\
\text { group } \\
(\mathrm{n}=6)\end{array}$ & $\begin{array}{c}* \mathrm{P} \\
\text { value }\end{array}$ \\
\hline MDA (nmol/ml) & $17.2 \pm 5.8^{\mathrm{ab}}$ & $5 \pm 2.1^{b}$ & $40 \pm 7.7^{\mathrm{ac}}$ & $12.4 \pm 2.8^{b}$ & $34.8 \pm 8.5^{\mathrm{ac}}$ & $31.08 \pm 9.85^{\mathrm{c}}$ & $<0.04$ \\
\hline SOD & $92.1 \pm 33.8^{\mathrm{a}}$ & $229.2 \pm 20.8^{\mathrm{b}}$ & $260.4 \pm 10.4^{\mathrm{b}}$ & $218.8 \pm 31.3^{\mathrm{b}}$ & $239.6 \pm 25.1^{\mathrm{b}}$ & $262.5 \pm 23.4^{b}$ & $<0.002$ \\
\hline CAT (U/L) & $563.1 \pm 54^{\mathrm{a}}$ & $988.4 \pm 3.6^{b}$ & $1017.4 \pm 7.9^{b}$ & $1033 \pm 4.6^{b}$ & $932.7 \pm 27.1^{\mathrm{b}}$ & $938.7 \pm 28.8^{\mathrm{b}}$ & $<0.004$ \\
\hline
\end{tabular}

Values are means \pm S.E.M. Values with different superscript letters within each row are significantly different (analysis of variance, $\mathrm{P}<0.05)$.

\section{DISCUSSION}

The present study evaluates the protective and therapeutic effects of $M$. oleifera on Leadinduced oxidative stress in blood cells, liver and kidneys as the most prominent target organs of the toxicity of these metals.

Moringa oleifera is a highly valued plant, distributed in many countries of the tropics and subtropics. It has an impressive range of medicinal uses with high nutritional value. Various parts of this plant, such as the leaves, roots, seed, bark, fruit, flowers and immature pods act as cardiac and circulatory stimulants, possess antitumor, antipyretic, antiepileptic, anti-inflammatory, antiulcer, antispasmodic, diuretic, antihypertensive, cholesterol lowering, antioxidant, antidiabetic, hepatoprotective, antibacterial and antifungal activities, and are being employed for the treatment of different ailments in the indigenous system of medicine (Anwar et al., 2007).

Lead is a common environmental toxic heavy metal that has no known biological function in the body and also it is known to induce a broad range of physiological, biochemical and behavioral dysfunctions in laboratory animals and humans, including affecting the central and peripheral nervous system, hematopoietic system, cardiovascular system, kidneys, liver and reproductive system (ATSDR, 2007).

The liver is considered the principal target organ for lead toxicity, the activity of ALT and AST are sensitive indicators of acute hepatic necrosis (Modesto et al., 2013).The liver is a vital organ with a wide range of functions such as detoxification, protein synthesis and production of biochemical necessary for digestion. It is actively involved in many metabolic functions and is the frequent target for a number of toxicants (Flora et al., 2003). Any hepatic damage is associated with distortion of these functions (Wolf, 1999). The absence of consistent hepatoprotective drugs in allopathic medicine, herbs demonstrate therapeutic functions in treatment of several liver damage and disorders (Buraimoh et al., 2011).

$\mathrm{Pb}$ hepatotoxicity has been related to the elevation in the levels of serum liver enzymes aspartate aminotransferase (AST) and alanine aminotransferase (ALT) (Omobowale et al., 2014) and alterations in hepatic cholesterol metabolism (Abdou and Hassan, 2014). This elevated may be due to hepatocellular necrosis, which caused increase in the permeability of the cell membrane resulting in the release of transaminases in the 
blood stream (Naik, 2010).

Exposure to lead for a short period affects the liver (Sivaprasad et al., 2004). In the present study, there was a significant increase in ALT level in therapeutic group compared to all other groups. Our findings are parallel with those obtained by Omobowale et al., (2014) and Onah et al., (2016) who reported increased liver enzymes after lead chlorides administration, which is an indication of impaired liver function, hepatocyte or biliary epithelial necrosis, compromise of hepatocyte membrane integrity, and cholestasis (Adaramoye et al., 2008). Also, there is nonsignificant decrease in AST level of lead injected rats then treated with Moringa oleifera. In addition, no significant elevation observed in total protein level, but Alain et al., (2016) found that total serum protein level decreased significantly in the lead-exposed group compared to control and rats treated with MO or the combination of lead and MO showed no significant variation in total protein level compared to control group.

Albumin decreased significantly in Mo group and the combination of lead and $\mathrm{MO}$ group compared to all other groups, which accordance with (Alain et al., (2016)) who found that the administration of lead chloride to Wistar rats induce a decrease in albumin levels.

The present study showed non-significant increase in total bilirubin and blood glucose level of lead injected rat group and MO group or association of both lead and $\mathrm{MO}$ when compared to control, which accordance with (Alain et al., 2016) who found similar to our findings. But Onah et al., (2016) who stated that total bilirubin levels increased significantly after 6 weeks of lead administration compared to their therapeutic group and other groups.

Cholesterol and triglyceride are the two major blood lipids. Cholesterol show significant decrease in Moringa olievera + Lead chloride group compared to all other groups, this result is in contrast with (Alain et al., (2016)) and (Hassan and Jassimm, 2010) who reported that no significant variation in the serum cholesterol level was noted in the experimental groups compared to the control. On the other hand, Blood triglyceride levels non-significant decrease in protective group, lead chloride group and lead chlorid\& $M O$ group compared to control group, also it shows that non-significant increase in therapeutic group and $M O$ group compared to control group. These results in contrast with (Hassan and Jassimm, 2010) who showed that the triglyceride levels significantly decreased in lead group.
Kidney is a target organ for lead toxicity. The toxic effects of $\mathrm{Pb}$ on the kidney appear to be primarily localized in the kidney tubule and are manifested as excessive urinary excretion of amino acids, glucose and phosphate, natriuresis, kaliuresis and intranuclear bodies inclusion (Jadhav et al., 2007). Lead affects the excretion function of nephrons, the structural and functional unit of the kidneys (Sivaprasad, et al., 2004a).

The present study showed that ammonia level was significant increase in therapeutic group compared to all other groups except control group. Also, urea was significantly increased in $M O$ \&lead chloride group than all other groups. On the other hand, creatinine was significantly decrease in Protective group compared to Moringa olievera and Therapeutic group. These findings were in agreement with Onah et al., (2016); Alain et al., (2016) and Lakshmana et al. (2013) who reported that $M O$ was found to be an effective herbal medicine in animal models of renal failure.

Also the uric acid level show non-significant change was found between treated groups and control. The current results clearly indicated that treatment with $M O$ shows protective role against renal cytotoxicity-induced by lead toxicity.

The present study, MDA shows significantly increase in Protective group compared to control, Moringa olievera and $M O \&$ Lead chloride group, these findings were in agreement with (Onah et al., 2016) who found that significant increase in lipid peroxidation index (MDA) of liver after the administration of lead when compared to the control group.

The most important consequence of $\mathrm{Pb}$-induced oxidative stress in liver is lipid peroxidation (Flora et al., 2003; Omobowale et al., 2014) that causes the alteration of membrane integrity and fatty acid composition (Lawton and Donaldson, 1991) and is associated with the increase in malondialdehyde (MDA) level in liver (Liu et al., 2012; Xu et al., 2008). Lead has the ability to bind to enzymes such as superox-ide dismutase (SOD) and catalase (CAT) (Patra et al., 2011).

The present study found a significant increase in SOD and CAT levels in all treated groups compared to control group which may be due to the presence of flavonoids such as quercetin and kaempferol, vitamin A, ascorbic acid, which is a potent antioxidant. Ouedraogo et al (2013); Bharali et al., (2003) and Sreelatha et al., (2009) suggesting therapeutic effect (antioxidant effect) of $M O$.

In the blood, haematimetric indices $(\mathrm{MCH})$, and Thrombocytes (TC) and Leucocytes (WBCs) 
showed significant increase on lead exposure, but the administration of $M O$ restored all the parameters back to controls also RBCS, hemoglobin and hematocrit showed no significant changes, in the contrast to Velaga et al., (2014) who observed significant decrease in lead group, this may be due to Acute bleeding and blood loss, Allergic reactions, Cancer, Chronic kidney failure or another kidney disorder, Exercise, Heart attack, Coronary artery bypass ,Infections, including tuberculosis, Iron deficiency, Vitamin deficiency, Removal of your spleen, Trauma, Burns, Exercise, Hemolytic anemia and Inflammation.

In conclusion, the present study revealed hepatorenal protective activities of $M O$ against lead toxicity and throw light on the effects of Moringa oleifera leaves powder have antitoxic properties. It has prevented some lead toxicities effect on many biochemical oxidative stress parameters of blood, kidney, liver and brain in albino rats so the $M O$ extract is recommended to pharmaceutical industries for further research and possible use in the manufacture of drugs.

\section{References}

Abdel Moneim, A.E., Dkhil, M.A. and Al-Quraishy, S. (2011): The protective effect of flaxseed oil on lead acetate-induced renal toxicity in rats. Journal of Hazardous Materials. 194:250-255.

Abdou, H.M. and Hassan, M.A. (2014): Protective role of omega-3 polyunsaturated fatty acid against lead acetate-induced toxicity in liver and kidney of female rats. Biomed. Res. Int.435857.

Adanaylo, V.N. and Oteiza, P.I. (1999): Lead Intoxication: Antioxidant Defenses and Oxidative Damage in Rat Brain. Toxicology. 135:77-85.

Adaramoye, O.A., Osaimoje, D.O., Akinsanya, A.M., Nneji, C.M., Fafunso, M.A. and Ademowo, O.G. (2008): Changes in Antioxidant Status and Biochemical Indices after Acute Administration of Artemether, Artemether-Lumefantrine and Halofantrine in Rats. Basic and Clinical Pharmacology and Toxicology. 102:412-418.

Adegbesan, B.O. and Adenuga, G.A. (2007): Effect of lead exposure on liver lipid peroxidative and antioxidant defense systems of proteinundernourished rats. Biol Trace Elem Res. 116:21925.

Agency for Toxic Substances and Disease Registry (ATSDR, 2007): Toxicological Profile for Lead. U.S. Department of health and Human Services. Public Health Service, Atlanta, GA.

Alain, A.K., Casimir D., Sègbo, J., Senou, M., Anago, E., Ahoyo, T.A., Klotoé, J.R., Edorh, P.A. and Loko, J.R.(2016): Attenuation effect of Moringa oleifera leaves powder on Blood Biochemical disturbance induced in lead-exposed rats. International Research Journal of Biological Sciences. 5: 14-21.

Anwar F, Latif S, Ashraf, M. and Gilani, A.H. (2007): Moringa oleifera: a food plant with multipurpose medicinal uses. J. Agric. Food Chem. 51: 65586563.

Bharali, R, Tabassum, J. and Azad, M.R.H. (2003): Chemomodulatory effect of Moringa oleifera Lam. on hepatic carcinogen metabolizing enzymes, antioxidant parameters and skin papillomagenesis in mice. Asian. Pac. J. Cancer. Prev. 4: 131-139.

Bokara, K.K., Brown, E., McCormick, R., Yallapragada, P.R., Rajanna, S. and Bettaiya, R. (2008): Lead-induced increase in antioxidant enzymes and lipid peroxidation products in developing rat brain. Biometal. 21: 9-16.

Bressler, J., Kim, K.A., Chakraborti, T. and Goldstein, G. (1999): Molecular mechanisms of lead neurotoxicity. Neurochem Res. 24: 595-600.

Buraimoh, A.A., Bako, I.G. and Ibrahim, F.B. (2011): Hepatoprotective Effect of Ethanolic Leaves Extract of Moringa oleifera on the Histology of Paracetamol Induced Liver Damage in Wistar Rat. International Journal of Animal and Veterinary Advances. 3: 10-13.

Flora, S.J., Pande, M. and Mehta, A. (2003): Beneficial effect of combined administration of some naturally occurring antioxidants (vitamins) and thiol chelators in the treatment of chronic lead intoxication. Chem. Biol. Interact. 145: 267-280.

Flora, S.J.S., Flora, G. and Saxena, G. (2016): Environmental occurrence, health effects and management of lead poisoning" In: Cascas SB, Sordo J, editors. Lead chemistry, analytical aspects, environmental impacts and health effects. Netherlands: Elsevier Publication. p. 158-228.

Gupta, R., Kannan, G.M., Sharma, M. and Flora, S.G. (2005): Therapeutic effect of Moringa oleifera in arsenic induced toxicity in rat. Envro Toxicol Pharmaco. 20:456-464.

Hassan, A.A. and Jassim, H.M. (2010): Effect of treating lactating rats with lead acetate and its interaction with vitamin $\mathrm{E}$ or $\mathrm{C}$ on neurobehavioral, development and some biochemical parameters in their pups. Iraqi Journal of Veterinary Sciences. 24:45-52.

Jadhav, S.H., Sarkar, S.N., Patil, R.D. and Tripathi, H.C. (2007): Effects of sub chronic exposure via drinking water to a mixture of eight watercontaminating metals: a biochemical and histopathological study in male rats. Arch. Environ. Contam. Toxicol. 53: 667-677.

Karrari, P., Mehrpour, O. and Abdollahi, M. (2012): A Systematic Review on Status of Lead Pollution and Toxicity in Iran; Guidance for Preventive Measures. DARU Journal of Pharmaceutical Sciences. 20:2.

Khalil-Manesh, F., Gonick, H.C., weiler, E.W., Prins, B., Weber, M.A. and Purdy, R.E. (1993): Leadinduced hypertension: possible role of endothelial 
factors. Am J Hypertens. 6: 723-9.

Kim, J. and O.h., J.M. (2013): Tissue distribution of metals inwhite-fronted geese and spot-billed ducks from Korea. Bull.Environ. Contam. Toxicol. 91: 18-22.

Lakshmana, G., Rajeshkumar, D., Ashok, R.P., Anil, K.M., Kiran, K.M., Divya, V.C., Divya, C. and Ram, S.K.B. (2013): Determination of Nephroprotective Activity of Ethanolic Leaf Extract of Moringa pterygosperma on Paracetamol induced Nephrotoxic Rats. International Journal of Allied Medical Sciences and Clinical Research. 1: 51-61.

Lancranjan, I., Popscu, H.I., G.A., vanescu, O., Klepsch, I. and Serbanescu, M. (1975): Reproductive ability of workmen occupationally exposed to lead. Arch Environ Health. 30: 396-401.

Lanphear, B.P., Dietrich, K., Auinger, P. and Cox, C. (2000): Cognitive deficits associated with blood lead concentrations $<10 \mu \mathrm{g} / \mathrm{dl}$ in adolescents and US children. Public Health Rep. 115: 521-9.

Lawton, L.J. and Donaldson, W.E. (1991): Leadinduced tissue fatty acid alterations and lipid peroxidation. Biol. Trace Elem. Res. 28: 83-97.

Liu, C.M., Ma, J.Q. and Sun, Y.Z. (2012): Puerarin protects the rat liver against oxidative stressmediated DNA damage and apoptosis induced by lead. Exp. Toxicol. Pathol. 64:575-582.

Lowell J.F. (2002): The Miracle Tree. ACP -EU, Dakar. 137-139.

Mahajan, S.G. and Mehta, A.A. (2008): Effect of Moringa oleifera Lam seed extract on ovalbumin induced airway inflammation in guinea pigs. Inhalation Toxicology. 20: 897-909.

Modesto Dos Santos, V., Da Costa Arruda Jr., Z., De FariasPolcheira, M., Da Silva De Souza, D.W., Rodrigues OliveiraSantos, A.M. and Santos Corrêa Da Costa, M. (2013): Acutehepatitis due to infectious mononucleosis in a 21- -year-old-man. Rev. Méd. Chil. 141: 917-921.

Moussa, S.A. and Bashandy, S.A. (2008): Biophysical and biochemical changes in the blood of rats exposed to lead toxicity. Romanian J. Biophys. 18(2): 123-133.

Mudipalli, A. (2007): Lead hepatotoxicity and potential healtheffects. Indian J. Med. Res. 126: 518-527.

Naik P. (2010): Biochemistry. Third ed. Panama. Jaypee Publishers Ltd. pp. 138-141.

Olorunnisola, O.S., Akintola, A.O. and Afolayan, A.J. (2011): Hepatoprotective and antioxidant effect of Sphenocentrum jollyanum (Menispermaceae) stem bark extract against $\mathrm{CCl} 4$ - induced oxidative stress in rats. Afr. J. Pharmc. Pharmacol. 5: 1241-1246.

Omobowale, T.O., Oyagbemi, A.A., Akinrinde, A.S., Saba, A.B., Oluwabusola T. Daramola, O.T., Ogunpolu, B.S. and Olopade, J.O. (2014): Failure of recovery from lead induced hepatoxicityand disruption of erythrocyte antioxidant defencesystem in Wistar rats. Environmental toxicology and pharmacology. 37:1202-1211.
Omotoso, B.R., Abiodun, A.A., Ijomone, O.M. and Adewole1, S.O. (2015): Lead-induced damage on hepatocytes and Hepatic reticular fibres in Rats; Protective Role of Aqueous Extract of Moringa oleifera Leaves (Lam). Journal of Biosciences and Medicines. 3: 27-35.

Onah,C.E.,Meludu,S.C., Dioka,C.E., Onuegbu,A.J., Onah,C.F., Ajaghaku,D.L., Nnodim,J.K. and Ejeatuluchukwu, O. (2016): Amelioratory Effect of Methanolic Leaf Extract of Moringa oleifera on Some Liver and Kidney Function and Oxidative Stress Markers in Lead-intoxicated Rats. European Journal of Medicinal Plants.12: 1-

Ouedraogo M., Lamien-Sanou A. and Ramde N. (2013): Protective effect of Moringa oleifera leaves against gentamicininduced nephrotoxicity in rabbits. Exp Toxicol Phathol. 65: 335-339.

Patil, A.J., Bhagwat, V.R., Patil, J.A., Dongre, N.N., Ambekar, J.G.,Jailkhani, R. and Das, K.K. (2006): Effect of lead $(\mathrm{Pb})$ exposure onthe activity of superoxide dismutase and catalase in batterymanufacturing workers (BMW) of Western Maharashtra(India) with reference to heme biosynthesis. Int. J. Environ.Res. Public Health. 3: 329-337.

Patra, R.C., Rautray, A.K. and Swarup, D. (2011): Oxidative stress inlead and cadmium toxicity and its amelioration. Vet. Med.Int. 457-327.

Rastogi, S.K. (2008): Renal effects of environmental and occupational lead exposure. Indian J. Occup. Environ. Med. 12: 103-106.

Ronis M.J.J, Bedger T.M and Shema S.J. (1998): Endocrine mechanism underlying the growth effects of developmental lead exposure in rat. $\mathbf{J}$ Toxicol Environ Health. 54: 101-20.

Sanchez M.D.I., Lopez C.J. and Vazquez N.J.R. (2006): High-performance liquid chromatography method to measure $\alpha$ - and $\square$-tocopherol in leaves, flowers and fresh beans from Moringa oleifera. J Chromatogr. 1105:111-114.

Sandhir R and Gill K.D. (1995): Effect of lead on lipid peroxidation in liver of rats. Biol Trace Elem Res. 48:91-7.

Saxena G. and Flora S.J.S. (2006): Changes in brain biogenic amines and heme-biosynthesis and their response to combined administration of succimer and Centella asiatica in lead poisoned rats. J Pharm Pharmacol. 58:547-59.

Sivaprasad T.R., Malarkodi S.P. and Varalakshmi P. (2004): Therapeutic efficacy of lipoic acid in combination with dimercaptosuccinic acid against leadinduced renal tubular defects and on isolated brushborder enzyme activities. Chemico-biological interactions. 147: 259-271.

Sivaprasad, T.R., Nagaraj, M. and Varalakshmi, P. (2004): Combined Efficacies of Lipoic Acid and 2, 3-Dimercaptosuccinic Acid against Lead-Induced Lipid Peroxidation in Rat Liver. Journal of Nutritional Biochemistry. 15: 18-23.

Skerfving, S. and Bergdahl, I.A. (2007): Lead. In: 
Nordberg, G.F., Fowler, B.A., Norberg, M. and Friberg, L.T., Eds., Handbook on the Toxicology of Metals, 3rd Edition, Academic Press, Amesterdam, 599-643.

Sousa, R.A., Sabarense, C.M., Prado, G.L., Metze, K. and Cadore, S. (2013): Lead bio monitoring in different organs of lead intoxicated rats employing GF AAS and different sample preparations. Talanta. 104: 90-96.

Sreelatha, S. and Padma, P.R. (2009): Antioxidant activity and total phenolic content of Moringa oleifera leaves in two stages of maturity. Plant Foods Human. Nutr. 64:303-311.

Toppo, R., Roy, B.K., Gora, R.H., Baxla, S.L. and Kumar, P. (2015): Hepatoprotective activity of Moringa oleifera against cadmium toxicity in rats. Veterinary World. 8:537-540.

Velaga, M.K., Daughtry, L.K., Jones, A.C., Yallapragada, P.R., Rajanna, s. and Rajanna, B.
(2014): Attenuation of Lead-Induced Oxidative Stress in Rat Brain ,liver,kidney and blood of male wistar rats by Moringa oleifera seed powder. J Environ Pathol Toxico Oncol. 4: 323-337.

Wadhwa S., Panwar S., Saini N., Rawat S., Singhal M. (2013): A review on commercial traditional uses phytoconstituents and pharmacological activity of Moringa oleifera. Global J Trad Med. 2: 1-13.

Wolf, P.L. (1999): Biochemical Diagnosis of Liver Disease. Indian Journal of Clinical Biochemistry. 14: 59-64.

Xu, J., Lian, L.J., Wu, C., Wang, X.F., Fu, W.Y. and $\mathrm{Xu}$, L.H., (2008): Lead induces oxidative stress, DNA damage and alteration of p53, Bax and Bcl-2 expressions in mice. Food Chem. Toxicol. 46: 1488-1494.

Yiin, S.J. and Lin, T.H. (1995): Lead-Catalyzed Peroxidation of Essential Unsaturated Fatty Acid. Biological Trace Element Research. 50: 167-172.

$$
\begin{aligned}
& \text { عنوان البحث: التأثير الوقائي والعلاجي لنبات المورينجا ضد سمية كلوريد الرصاص } \\
& \text { قدرى البكرى'، نجلاء العربانى' ، سماء بحيرى' } \\
& \text { ' قسم علم لحيوان - كلية العلوم - جامعة دمياط }
\end{aligned}
$$

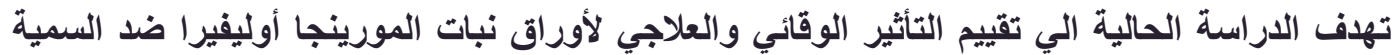

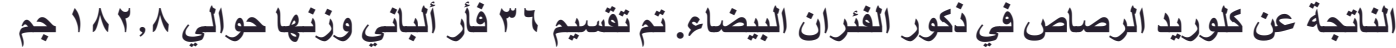

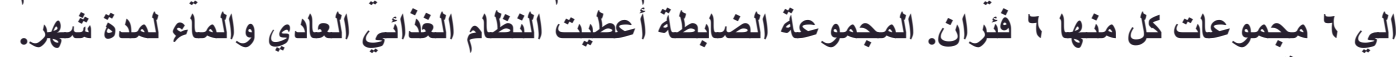

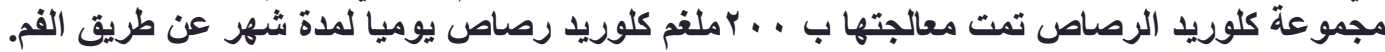

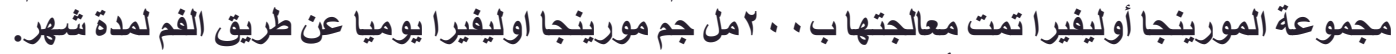

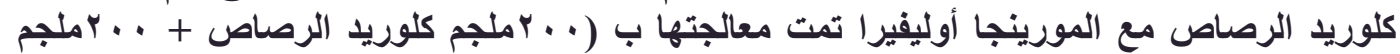

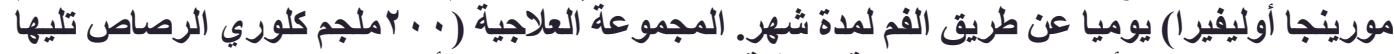

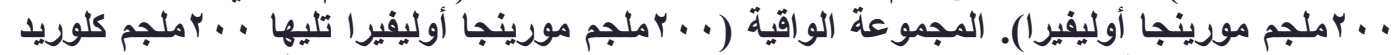

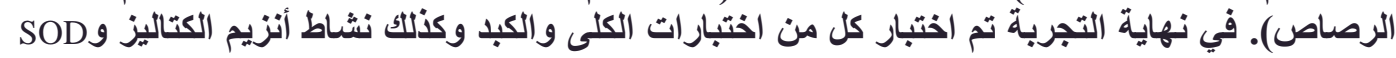

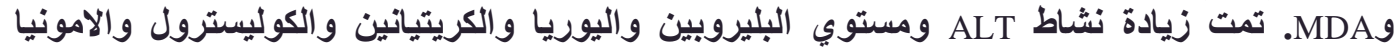

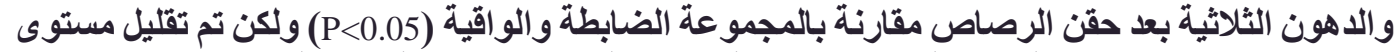

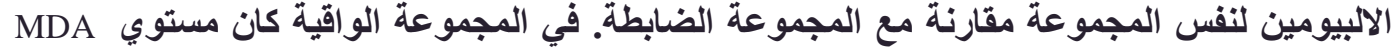

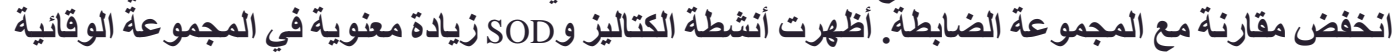

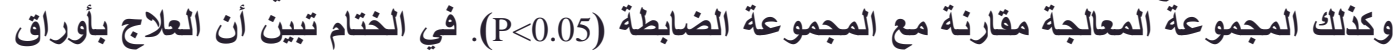
نبات المورينجا أوليفيرا يمكن ان تحمي الكبا والكلي ضد سمية كلوريد الرصاص. فيطا. 